\title{
Penelitian Pendahuluan
}

\section{Profil Penggunaan Antidiabetik pada Pasien Diabetes Melitus Gestasional di Puskesmas Wilayah Kecamatan Pontianak Kota}

\author{
Kharina Anisya, Robiyanto, Nurmainah \\ Program Studi Farmasi Fakultas Kedokteran, Universitas Tanjungpura, Pontianak, Indonesia
}

\begin{abstract}
Abstrak
Pada masa kehamilan, terjadi perubahan-perubahan fisiologis yang berpengaruh terhadap metabolisme karbohidrat sehingga mengakibatkan kehamilan tersebut bersifat diabetogenik. Berbagai faktor dapat mengganggu keseimbangan metabolisme karbohidrat dengan meningkatnya usia kehamilan sehingga terjadi gangguan toleransi glukosa. Keadaan ini dikenal dengan diabetes melitus gestasional (DMG). DMG termasuk jenis penyakit diabetes melitus (DM) yang terjadi pada saat kehamilan. DMG, jika tidak ditangani dengan tepat, dapat berisiko menjadi DM tipe 2 di masa mendatang. Untuk itu, pengobatan DMG perlu dilakukan dengan pendekatan nonfarmakologi dan farmakologi untuk mencegah terjadinya DM tipe 2 dalam jangka waktu yang panjang. Penelitian ini bertujuan untuk mendeskripsikan penggunaan antidiabetik pada pasien diabetes melitus gestasional di Puskesmas Wilayah Kecamatan Pontianak Kota. Penelitian ini menggunakan metode observasional dengan rancangan penelitian potong lintang yang bersifat deskriptif. Pengumpulan data dilakukan secara retrospektif berdasarkan data rekam medis pasien DMG rawat jalan di Puskesmas Wilayah Kecamatan Pontianak Kota periode Januari 2016September 2017. Sampel penelitian yang memenuhi kriteria inklusi sebanyak 32 pasien. Dari hasil penelitian, diperoleh obat yang dominan digunakan untuk mengatasi DMG pada wanita hamil adalah metformin $(78,13 \%)$ yang merupakan golongan biguanida, dan sisanya menggunakan gliburid $(21,88 \%)$ yang merupakan golongan sulfonilurea. Simpulan dari penelitian ini adalah golongan biguanida banyak digunakan untuk mengatasi DMG pada wanita hamil trimester kedua dan ketiga.
\end{abstract}

Kata kunci: Diabetes melitus gestasional, gliburid, metformin

\section{Antidiabetic Use Profile on Gestasional Diabetes Mellitus Patients at Community Health Center in Region of Center Pontianak}

\begin{abstract}
During pregnancy, there are physiological changes affecting on carbohydrate metabolism which cause a diabetogenic pregnancy. Various factors can disrupt the balance of carbohydrate metabolism with increasing gestational age, resulting in impaired glucose tolerance. This condition is known as gestational diabetes mellitus (GDM). GDM is a type of diabetes mellitus (DM) that occurs during pregnancy. GDM, if not handled properly, can be at risk of becoming type 2 DM in the future. Therefore, GDM treatment needs to be done with non-pharmacology and pharmacology approach to prevent the occurrence of DM type 2 in the long term. The objective of this research was to describe the use of oral antidiabetics on gestational diabetes mellitus patients at community health center in Region of Center Pontianak. This research employed observational method with descriptive cross-sectional study design. The data collection was done from medical record of gestasional diabetes mellitus outpatients at community health center in Region of Center Pontianak in the period of January 2016-September 2017. A total of 32 patients fulfilled the inclusion criteria. The results showed that drugs dominantly taken as GDM treatment during pregnancy was metformin $(78.13 \%)$ which is biguanide group, while the rest was glyburide $(21.88 \%)$ which is sulfonylurea group. The conclusion of this research is biguanide group was mostly used to treat GDM for pregnancy during the second trimester and third trimester.
\end{abstract}

Keywords: Gestational diabetes mellitus, glyburide, metformin

Korespondensi: Kharina Anisya, S.Farm., Program Studi Farmasi Fakultas Kedokteran, Universitas Tanjungpura, Pontianak, Kalimantan Barat 78115, Indonesia, email: khareenanisya@gmail.com

Naskah diterima: 15 Februari 2018, Diterima untuk diterbitkan: 8 September 2018, Diterbitkan: 1 Maret 2019 


\section{Pendahuluan}

Pada saat masa kehamilan, terjadi perubahan metabolisme endokrin dan karbohidrat untuk nutrisi pada janin dan persiapan menyusui. Kondisi ini memiliki pengaruh pada pankreas ibu hamil, sehingga terjadi suatu peningkatan produksi insulin yang dapat meningkatkan kadar glukosa darah yang dikenal sebagai hiperglikemia. Kejadian hiperglikemia pada ibu hamil disebut diabetes melitus gestasional (DMG). ${ }^{1-3}$ DMG, jika tidak ditangani dengan tepat, dapat berisiko menjadi diabetes melitus (DM) tipe 2 di masa mendatang. ${ }^{4}$

Prevalensi penderita DMG setiap tahunnya berkisar 3-5\% di seluruh dunia. Prevalensi DMG di Amerika Serikat yaitu sekitar 4\%, di Inggris sebesar 3-5\%, di Eropa sebesar $2-6 \%,{ }^{1,5}$ dan di Indonesia sebesar 1,9-3,6\%. ${ }^{6-7}$ Pengobatan DMG dalam rangka mencegah komplikasi yang muncul dapat dilakukan melalui pendekatan secara nonfarmakologi dan farmakologi. Pengobatan nonfarmakologi dilakukan melalui pengaturan diet berdasar pada pedoman diet Medical Nutrition Therapy (MNT) dan pemantauan glukosa darah atau Self Monitoring of Blood Glucose (SMBG).

Pengobatan dengan pendekatan farmakologi dilakukan dengan cara pemberian insulin, yang pemberiannya dilakukan apabila belum tercapai normoglikemia melalui pengaturan diet yang telah dijalankan. ${ }^{1}$ Insulin yang dapat diberikan adalah insulin kerja pendek (shortacting) seperti humulin $\mathrm{R}$, insulin kerja sedang (intermediate-acting) seperti isophane atau insulin kerja cepat (rapid-acting) seperti aspart dan lispro. ${ }^{8,9}$ Penggunaan obat hipoglikemik oral $(\mathrm{OHO})$ hanya dapat diberikan sebagai alternatif terapi DMG apabila insulin tidak tersedia di fasilitas kesehatan. OHO yang disarankan untuk mengatasi DMG hanya gliburid dan metformin. Kedua obat ini tidak menyebabkan teratogenitas. ${ }^{8-10}$

Sejauh ini, pengobatan DMG lebih berfokus pada pengobatan farmakologi yang dilakukan melalui penggunaan insulin baik secara tunggal atau kombinasi dengan $\mathrm{OHO}$, serta keamanan suatu obat untuk ibu hamil menjadi faktor utama. DMG yang tidak ditangani dengan tepat akan menyebabkan komplikasi yang signifikan dan sangat berpotensi bagi ibu dan janin termasuk makrosomia janin, komplikasi metabolik dan kematian perinatal, serta meningkatkan risiko bagi ibu sebesar 3-5\% untuk menderita DM tipe 2 di masa mendatang. ${ }^{4}$ Oleh karena itu, penanganan DMG yang telah dilakukan perlu diketahui, mengingat $\mathrm{DMG}$ merupakan faktor risiko dari DM tipe 2 yang dapat berakibat fatal baik terhadap ibu maupun janin jika tidak ditangani dengan tepat. Berdasarkan uraian di atas, peneliti tertarik untuk meneliti dan mendeskripsikan penggunaan dari obat-obat antidiabetik pada pasien DMG di Puskesmas Wilayah Kecamatan Pontianak Kota.

\section{Metode}

Metode yang digunakan pada penelitian ini adalah metode observasional dengan rancangan penelitian studi potong lintang yang bersifat deskriptif, dan pengumpulan data dilakukan secara retrospektif yang berupa data sekunder, yakni data rekam medis pasien yang memuat data karakteristik pasien dan data pengobatan pada pasien DMG rawat jalan di Puskesmas Wilayah Kecamatan Pontianak Kota pada bulan Januari 2016 sampai September 2017. Pengumpulan data dilakukan di Puskesmas Wilayah Kecamatan Pontianak Kota sebab jumlah subjek penelitian yang terdiagnosis DMG lebih besar, yakni sebanyak 40 kasus pertahunnya. Selain itu, Puskesmas menjadi tempat pelayanan pertama dan utama bagi sebagian besar masyarakat dengan ekonomi menengah ke bawah. Subjek penelitian yang harus diambil dihitung dengan berdasarkan hitungan besaran sampel dengan menggunakan formula Slovin (Taro Yamane) ${ }^{11}$ dan diperoleh hasil sedikitnya 32 subjek penelitian dengan 
perhitungan besaran sampel sebagai berikut:

$$
\mathrm{n}=\frac{\mathrm{N}}{1+\mathrm{N}\left(\mathrm{d}^{2}\right)}
$$

Keterangan:

$\mathrm{n}=$ besaran sampel minimum;

$\mathrm{N}=$ jumlah populasi;

$\mathrm{d}=$ kesalahan (absolut) yang dapat diukur/ derajat akurasi $=10 \%=0,1$.

$$
\mathrm{n}=\frac{41}{1+41\left(0,1^{2}\right)}
$$

Diperoleh $\mathrm{n}=29,07 \approx 29$. Kemudian sampel dilebihkan 10\%, sehingga diperoleh 29+2,9= $31,9 \approx 32$. Jadi, besaran sampel minimum yang dibutuhkan untuk penelitian ini sebanyak 32 pasien.

Kriteria inklusi dalam penelitian ini adalah pasien yang terdiagnosis DMG dengan kadar gula darah sewaktu (GDS) sebesar >140 mg/ dL dan pasien DMG pada wanita hamil usia $>30$ tahun. Hal ini dikarenakan berdasarkan hasil penelitian Hosler et al., ${ }^{12}$ wanita hamil yang berusia $>30$ tahun lebih berisiko tinggi untuk mengalami DMG. Data yang diperoleh dan dianalisis secara deskriptif meliputi data karakteristik pasien (usia, berat badan, tinggi badan, usia kehamilan, dan hasil laboraturium berupa kadar gula darah sewaktu) dan data pengobatan (jenis obat, dosis obat, frekuensi penggunaan obat, dan waktu penggunaan obat). Data dianalisis menggunakan komputer dengan Microsoft Excel. Penelitian ini telah mendapatkan kelaikan etik dari Komisi Etik Penelitian Fakultas Kedokteran Universitas Tanjungpura dengan nomor 240/UN22.9/DL $/ 2018$.

\section{Hasil}

Berdasarkan hasil observasi data selama 2 (dua) tahun, diperoleh sebanyak 32 subjek yang memenuhi kriteria inklusi penelitian ini. Karakteristik subjek penelitian dapat dilihat pada Tabel 1. Pasien yang didiagnosis DMG dalam penelitian ini rata-rata berusia \pm 35 tahun dan sebagian besar memiliki riwayat obesitas. Rata-rata indeks massa tubuh (IMT) pasien DMG adalah $31,07 \mathrm{~kg} / \mathrm{m}^{2}$, dengan IMT maksimum $39 \mathrm{~kg} / \mathrm{m}^{2}$ dan IMT minimum $26 \mathrm{~kg} /$ $\mathrm{m}^{2}$.

Kejadian DMG cenderung terjadi pada kehamilan trimester ketiga (pada saat usia kehamilan 28-40 minggu) bila dibandingkan trimester kedua. Persentase kejadian DMG pada usia kehamilan tersebut sebesar 90,63\%, yang dapat dilihat pada Gambar 1. Akan tetapi, rata-rata kadar gula darah sewaktu pada kehamilan trimester ketiga lebih rendah bila dibandingkan rata-rata kadar gula darah sewaktu pada kehamilan trimester kedua. Pada Gambar 2, dapat dilihat bahwa rata-rata kadar gula darah sewaktu pada trimester ketiga adalah sebesar 187,86 mg/dL, sedangkan pada trimester kedua adalah sebesar 213,67 mg/dL. Secara keseluruhan, kadar rata-rata gula darah sewaktu pada pasien DMG adalah 190,28 mg/dL yang disajikan pada Tabel 1 .

Pengobatan farmakologi yang digunakan untuk mengatasi DMG pada wanita hamil adalah OHO. Tampak pada Tabel 2 bahwa penggunaan metformin (golongan biguanida) 78,13\% lebih banyak dibandingkan gliburid (golongan sulfonilurea). Berdasarkan Tabel 3, dapat diketahui bahwa frekuensi pemakaian

Tabel 1 Karakteristik Subjek Penelitian

\begin{tabular}{llrrrr}
\hline \multirow{2}{*}{ No. } & \multicolumn{2}{c}{ Karakteristik } & \multicolumn{3}{c}{$\mathbf{N}=\mathbf{3 2}$} \\
\cline { 3 - 6 } & & Mean & Median & Minimum & Maksimum \\
\hline 1 & Usia pasien (tahun) & 35,09 & 36,00 & 31 & 40 \\
2 & Usia kehamilan (minggu) & 30,00 & 29,50 & 24 & 37 \\
3 & Kadar gula darah sewaktu/GDS (mg/dL) & 190,28 & 166,00 & 142 & 332 \\
4 & Indeks massa tubuh $\left(\mathrm{kg} / \mathrm{m}^{2}\right)$ & 31,07 & 30,86 & 26 & 39 \\
\hline
\end{tabular}




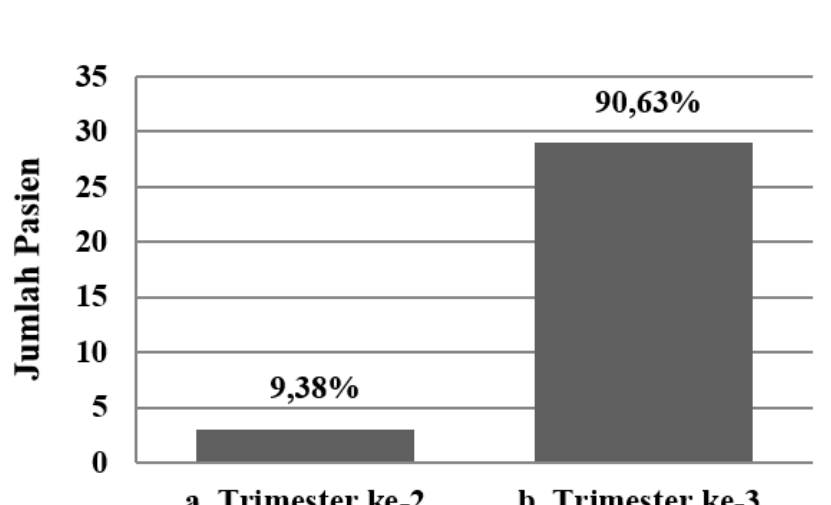

$\mathbf{N}=32$

a. Trimester ke-2 $\quad$ b. Trimester ke-3

Usia Kehamilan

Gambar 1 Distribusi Pasien Berdasarkan Usia Kehamilan

OHO, metformin $850 \mathrm{mg}$ digunakan dua kali sehari sedangkan gliburid $5 \mathrm{mg} 1$ kali sehari. Secara keseluruhan, waktu penggunaan obat metformin lebih sering dikonsumsi setelah makan $(60 \%)$ sedangkan gliburid dikonsumsi sebelum makan $(71,43 \%)$ seperti yang terlihat pada Tabel 4.

\section{Pembahasan}

Usia merupakan salah satu di antara banyak faktor risiko yang memiliki pengaruh pada terjadinya DMG. Pada Tabel 1, dapat dilihat bahwa pasien DMG berusia antara 31 tahun hingga 40 tahun. Hal ini menunjukkan bahwa usia pasien DMG berada pada usia 35 tahun atau lebih. Rentang usia tersebut merupakan faktor risiko untuk terjadinya DMG dan peningkatan morbiditas serta mortalitas pada ibu maupun janin. Hosler et al. menyatakan bahwa wanita hamil yang berusia 35 tahun atau lebih berisiko 4,05 kali untuk menderita DMG apabila dibandingkan dengan wanita hamil dengan usia $<25$ tahun. ${ }^{12}$ Usia memiliki hubungan yang sangat erat kaitannya dengan kenaikan kadar gula darah. Semakin tinggi

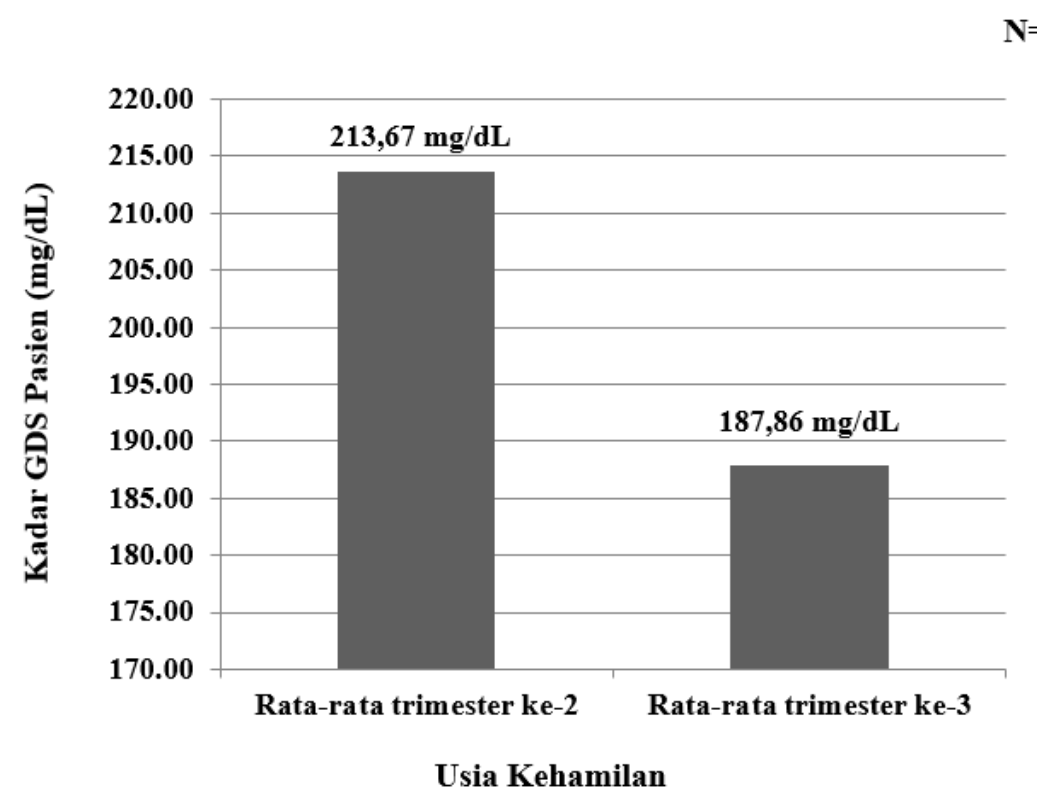

Gambar 2 Distribusi Kadar Rata-Rata Gula Darah Sewaktu (GDS) pada Pasien Berdasarkan Trimester Kehamilan 
Tabel 2 Distribusi Penggunaan Obat Hipoglikemik Oral (OHO)

\begin{tabular}{cllcr}
\hline \multirow{2}{*}{ No. } & \multirow{2}{*}{ Golongan } & Nama Obat & \multicolumn{2}{c}{$\mathbf{N = 3 2}$} \\
\cline { 4 - 5 } & & & Jumlah Pasien & Persentase (\%) \\
\hline 1 & Golongan Sulfonilurea & Gliburid & 7 & 21,88 \\
2 & Golongan Biguanida & Metformin & 25 & 78,13 \\
& Total & & $\mathbf{3 2}$ & $\mathbf{1 0 0 , 0 0}$ \\
\hline
\end{tabular}

usia, maka prevalensi diabetes dan gangguan toleransi glukosa semakin tinggi. ${ }^{12}$ Selain itu, kejadian DMG cenderung tinggi pada usia yang tua diperkirakan terjadi akibat adanya pengaruh dari proses penuaan dan kerusakan endotel pembuluh darah yang progresif. ${ }^{12}$

Rata-rata kadar gula darah sewaktu pasien yang mengalami DMG adalah 190,28 mg/dL. Rata-rata kadar GDS mulai meningkat pada kehamilan trimester kedua. Namun demikian, persentase kejadian DMG cenderung lebih banyak pada ibu hamil dengan usia kehamilan trimester ketiga bila dibandingkan trimester kedua jika dilihat dari hasil pada Gambar 1. Hal ini dikarenakan hampir semua pasien melakukan pemeriksaan kadar GDS pertama kali pada saat usia kehamilan adalah trimester ketiga dan kemudian diketahui bahwa pasien terdiagnosis DMG. Pemeriksaan DMG yang dijalani oleh pasien di Puskesmas Wilayah Kecamatan Pontianak Kota dilakukan dengan cara pemeriksaan GDS.

Pemeriksaan kadar GDS pada trimester ketiga (yakni usia kehamilan 28-40 minggu) cenderung lebih banyak apabila dibandingkan dengan trimester kedua (usia 13-27 minggu) seperti yang terlihat pada Gambar 1. Hal ini dikarenakan pada saat usia kehamilan berada pada trimester kedua dan ketiga rentan terjadi peningkatan kadar GDS akibat dari terjadinya perubahan respon hormonal pada wanita hamil, yaitu peningkatan kadar estrogen, progesteron, kortisol dan human placental lactogen (HPL), sehingga mengakibatkan wanita hamil gagal dalam mempertahankan glukosa darah (euglycemia). Tingginya kadar GDS wanita hamil menurut Cunningham dapat meningkatkan risiko terjadi DM tipe 2 pada wanita hamil sebesar $17-63 \%$ dalam kurun waktu 5-16 tahun. ${ }^{13}$

Berdasarkan pedoman penatalaksanaan diabetes melitus di Indonesia yang dibuat oleh Perkumpulan Endokrinologi Indonesia (PERKENI), ${ }^{14}$ pemeriksaan DMG pada wanita hamil adalah menggunakan metode WHOTTGO (tes toleransi glukosa oral-75 gram) untuk mengukur kadar glukosa plasma puasa dan kadar glukosa plasma pada saat 2 jam setelah pemberian glukosa. Hasil diagnosis uji TTGO dikategorikan dalam 2 kelompok, yaitu toleransi glukosa terganggu (TGT) atau glukosa darah puasa terganggu (GDPT) bergantung dari hasil uji yang diperoleh. Jika hasil pemeriksaan TTGO diperoleh glukosa plasma puasa sebesar $<140 \mathrm{mg} / \mathrm{dL}$, maka dikategorikan sebagai GDPT, sedangkan jika

Tabel 3 Distribusi Dosis dan Frekuensi Penggunaan Obat Hipoglikemik Oral (OHO)

\begin{tabular}{|c|c|c|c|c|c|}
\hline Golongan OHO & $\begin{array}{l}\text { Sediaan Obat } \\
\text { (tablet) }\end{array}$ & $\begin{array}{l}\text { Dosis } \\
\text { (mg) }\end{array}$ & $\begin{array}{c}\text { Frekuensi } \\
\text { Pemakaian }\end{array}$ & $\begin{array}{c}\text { Persentase } \\
(\%)\end{array}$ & $\begin{array}{c}\text { Rata-Rata } \\
\text { Kadar GDS } \\
(\mathrm{mg} / \mathrm{dL})\end{array}$ \\
\hline \multirow[t]{2}{*}{ Golongan Sulfonilurea } & Gliburid & 5 & $1 \mathrm{kali}$ & 71,43 & 147,60 \\
\hline & & 2,5 & 2 kali & 28,57 & 147,50 \\
\hline \multirow[t]{3}{*}{ Golongan Biguanida } & Metformin & 500 & 1 kali & 8 & 155,50 \\
\hline & & 850 & 2 kali & 60 & 227,27 \\
\hline & & 500 & 3 kali & 32 & 167 \\
\hline
\end{tabular}


Tabel 4 Distribusi Waktu Penggunaan Obat Hipoglikemik Oral (OHO)

\begin{tabular}{lccc}
\hline \multicolumn{1}{c}{ Golongan OHO } & Sediaan Obat (tablet) & Waktu Penggunaan & Persentase (\%) \\
\hline \multirow{2}{*}{ Golongan Sulfonilurea } & Gliburid & a.c & 71,43 \\
& & p.c & 28,57 \\
Golongan Biguanida & Metformin & a.c & 8 \\
& & d.c & 24 \\
& & p.c & 68 \\
\hline Keterangan: a.c (ante coenam)=sebelum makan; d.c (durante coenam) $=$ saat makan; p.c (post coenam) $=$ setelah makan
\end{tabular}

Keterangan: a.c $($ ante coenam $)=$ sebelum makan; d.c $($ durante coenam $)=$ saat makan; p.c $($ post coenam $)=$ setelah makan

kadar glukosa plasma 2 jam setelah beban berkisar antara 140-199 mg/dL, maka masuk ke dalam kelompok TGT. Bagi wanita hamil, kelompok TGT harus ditangani sebagai DM pada kehamilan. ${ }^{6,14}$

Adanya perbedaan tatalaksana penegakan diagnosis pada pasien DMG di Puskesmas tersebut dengan pedoman pengobatan DMG yang direkomendasikan oleh PERKENI dikarenakan lemahnya penerapan pedoman tersebut di Puskesmas, dan hal ini menjadi keterbatasan penelitian ini. Terdapat beberapa parameter skrining dan diagnosis untuk mengetahui adanya DMG, tetapi yang sering digunakan parameter skrining berdasarkan O'Sullivan Mahan yaitu American Diabetes Association (ADA) dan WHO, ${ }^{3,6,14}$

Obat-obatan yang dapat digunakan untuk mengatasi DMG berdasarkan rekomendasi WHO yaitu insulin sebagai first-line therapy, metformin, serta gliburid. Jenis insulin yang dapat diberikan adalah insulin kerja pendek (short-acting) seperti humulin $\mathrm{R}$, insulin kerja sedang (intermediate-acting) seperti isophane, atau insulin kerja cepat (rapidacting) seperti aspart dan lispro. Penggunaan obat terbanyak berdasarkan Tabel 2 adalah metformin (golongan biguanida). Metformin merupakan antidiabetik yang aman digunakan untuk wanita hamil karena tidak melintasi plasenta. Hal ini sejalan dengan penelitian yang dilakukan oleh Rowan et al. ${ }^{15}$ yang menyatakan bahwa metformin sebagai obat tunggal atau kombinasi dengan insulin baik digunakan pada wanita hamil dengan DMG. Penggunaan metformin tidak menunjukkan adanya peningkatan komplikasi perinatal. Dari sisi pemakaiannya, metformin lebih mudah dan ekonomis apabila dibandingkan insulin, sehingga lebih dapat diterima oleh pasien. Metformin juga dapat menurunkan glukosa darah dalam waktu satu minggu dan menurunkan glukosa darah 2 jam postprandial. $^{15}$

Penggunaan OHO lainnya yang digunakan pada pasien DMG adalah gliburid. Gliburid merupakan obat golongan sulfonilurea yang memperlihatkan transfer plasenta yang minimal karena ikatannya dengan protein yang tinggi dan tidak menunjukkan adanya keterkaitan dengan hipoglikemia pada janin. ${ }^{15,16}$ Hal yang membedakan pengobatan pada pasien DMG dengan DM lainnya adalah pemilihan obat yang benar-benar aman dan tidak melintasi plasenta untuk digunakan pada wanita hamil sehingga tidak menimbulkan pengaruh buruk (komplikasi) bagi ibu maupun janin. ${ }^{15-17}$

Penggunaan metformin pada ibu hamil termasuk dalam kategori B menurut Food and Drug Administration (FDA). Kategori ini menunjukkan bahwa obat tersebut telah diuji pada reproduksi hewan percobaan dan tidak memperlihatkan adanya risiko terhadap fetus, serta tidak memperlihatkan adanya efek samping. Gliburid termasuk ke dalam kategori C, yaitu uji pada hewan percobaan memperlihatkan adanya efek samping pada fetus (teratogenik, embriosidal, atau lainnya) dan tidak ada studi terkontrol pada wanita hamil. Obat-obatan hanya dapat diberikan jika manfaat yang diperoleh sebanding dengan besarnya potensi risiko terhadap janin. Obat- 
obatan dalam kategori A dan B umumnya dianggap tepat digunakan selama kehamilan. Obat-obatan pada kategori $\mathrm{C}$ harus digunakan dengan peringatan, dan obat-obatan kategori $\mathrm{D}$ dan $\mathrm{X}$ harus dihindari atau merupakan kontraindikasi. ${ }^{18}$

Distribusi dosis dan frekuensi antidiabetik yang diberikan pada pasien DMG berbedabeda dan dapat dilihat pada Tabel 3. Hal ini dikarenakan pemberian dosis dan frekuensi antidiabetiknya harus disesuaikan dengan kondisi fisiologis pasien. Hasil penelusuran hasil data rekam medis menunjukkan ratarata pasien yang mendapatkan metformin memiliki riwayat obesitas, dengan demikian obat yang sesuai agar tidak menyebabkan kenaikan berat badan adalah metformin. Berdasarkan Tabel 4, diketahui bahwa waktu penggunaan obat gliburid yang paling sering adalah sebelum makan $(71,43 \%)$. Hal ini dikarenakan obat-obat golongan sulfonilurea dapat menyebabkan hipoglikemia sehingga pemberiannya harus diberikan pada saat sebelum makan (15-30 menit). ${ }^{14}$ Sementara itu, metformin banyak dikonsumsi setelah makan (68\%). Metformin mempunyai efek samping yang menyebabkan mual, sehingga harus dikonsumsi setelah makan atau satu suapan pertama setelah makan. ${ }^{14}$

Penanganan DMG menurut Kaaja et al. ${ }^{19}$ dapat dilakukan terlebih dahulu dengan terapi nonfarmakologi yaitu terapi diet MNT. Terapi ini merupakan strategi utama dalam mencapai kontrol glikemik. ${ }^{19}$ Konsentrasi glukosa darah dapat dikontrol melalui perencanaan pola makan. Prinsip pengaturan makan pada pasien DMG yaitu makanan yang seimbang dan sesuai dengan kebutuhan kalori dan zat gizi masing-masing individu. Diet yang dilakukan yaitu diet karbohidrat, protein dan lemak. Karbohidrat yang dianjurkan sebesar 45-65\% total asupan energi, asupan lemak dianjurkan sekitar 20-25\% kebutuhan kalori dan asupan protein sebesar $10-20 \%$ total asupan energi.
Selain diet, aktivitas fisik/latihan jasmani juga dapat dilakukan yang selain bermanfaat untuk menjaga kebugaran, juga menurunkan berat badan dan memperbaiki sensitivitas insulin, sehingga akan memperbaiki kendali glukosa darah. Latihan jasmani yang sangat dianjurkan yaitu yang bersifat aerobik dengan intensitas sedang (50-70\% denyut jantung maksimal), seperti jalan cepat, bersepeda santai, jogging, serta berenang. Penelitian ini hanya menggunakan pengumpulan data berupa retrospektif dengan mengumpulkan data rekam medik pasien DMG, sehingga tidak terlihat penanganan DMG dengan terapi diet. Hal ini merupakan keterbatasan pada penelitian ini dalam penegakan manajemen pengobatan DMG pada wanita hamil.

Kenaikan berat badan selama kehamilan dipengaruhi oleh berat badan sebelum hamil. Rekomendasi penambahan berat badan bagi wanita hamil adalah sekitar $7 \mathrm{~kg}$ pada wanita obesitas, dan $18 \mathrm{~kg}$ pada wanita dengan berat badan kurang $\left(18,5 \mathrm{~kg} / \mathrm{m}^{2}\right)$ sebelum kehamilan. ${ }^{20}$ Dalam penelitian ini, hasil data menunjukkan bahwa sebagian besar pasien DMG memiliki riwayat obesitas. Hal ini sejalan dengan pernyataan Cheung et al., ${ }^{21}$ yang menyatakan bahwa seseorang dengan IMT berada dalam kategori overweight atau obesitas berisiko terkena DMG dibandingkan dengan seseorang yang mempunyai IMT normal atau underweight pada saat sebelum kehamilan. Overweight merupakan faktor risiko pada gangguan toleransi glukosa baik sebelum atau dalam kehamilan. Overweight merupakan manifestasi dari obesitas, dengan kata lain overweight merupakan suatu tahap sebelum terjadi obesitas. ${ }^{21}$ Hosler et al. ${ }^{12}$ juga menyatakan bahwa ibu yang memiliki riwayat overweight berisiko 1,53 kali untuk menderita DMG, sedangkan pada ibu yang memiliki risiko obesitas berisiko 2,59 kali untuk menderita DMG dibandingkan dengan ibu yang tidak memiliki riwayat obesitas. Penelitian relevan lainnya oleh Chu et al., ${ }^{22}$ 
didapatkan hasil bahwa ibu yang memiliki riwayat obesitas memiliki risiko $3,56 \mathrm{kali}$ untuk menderita DMG dibandingkan ibu yang tidak memiliki riwayat obesitas.

Pada kondisi obesitas, sel-sel lemak yang menggemuk akan menghasilkan beberapa zat yang digolongkan sebagai adipositokin yang jumlahnya lebih banyak dibandingkan keadaan tidak gemuk. ${ }^{23}$ Zat-zat itulah yang dapat menyebabkan resistensi insulin dan mengakibakan glukosa sulit masuk ke dalam sel. Keadaan ini membuat glukosa darah tetap tinggi (hiperglikemia) dan terjadi diabetes. Selain itu, umumnya pada saat hamil terjadi penambahan berat badan dan peningkatan konsumsi makanan yang memiliki dampak pada peningkatan gula darah di atas normal. Oleh karena itu, perlu dilakukan penjagaan pola makan sebelum hamil untuk mencegah peningkatan berat badan berlebih saat hamil.

\section{Simpulan}

Pengobatan terbanyak yang diberikan untuk pasien diabetes melitus gestasional (DMG) di Puskesmas Wilayah Kecamatan Pontianak Kota adalah terapi metformin $(78,13 \%)$ yakni pada 25 pasien dari total 32 pasien DMG, dan sebanyak 7 pasien memperoleh gliburid $(21,88 \%)$. Metformin termasuk dalam obat ketegori B sehingga relatif aman digunakan pada ibu hamil. Oleh karena itu, diperlukan kontrol dan pemeriksaan rutin pada wanita hamil serta kontrol penggunaan obat-obatan yang aman dan rasional. Kadar rata-rata gula darah sewaktu dari pasien DMG cenderung mengalami peningkatan pada trimester kedua (13-27 minggu) sebesar 213,67 mg/dL.

\section{Ucapan Terima Kasih}

Terima kasih kepada seluruh pihak yang terlibat dalam penelitian ini, dan kepada Puskesmas Wilayah Kecamatan Pontianak Kota yang telah berkenan memberikan kesempatan dan tempat untuk melakukan penelitian.

\section{Pendanaan}

Penelitian ini dilakukan tanpa bantuan atau hibah dari manapun.

\section{Konflik Kepentingan}

Seluruh penulis menyatakan tidak terdapat potensi konflik kepentingan dengan penelitian, kepenulisan (authorship) dan atau publikasi artikel ini.

\section{Daftar Pustaka}

1. Buckley BS, Harreiter J, Damm P, Corcoy R, Chico A, Simmons D, et al. Gestational diabetes mellitus in Europe: Prevalence, current screening practice and barriers to screening. Diabet Med. 2012; 29(7): 844 54. doi: 10.1111/j.1464-5491.2011.03541 .x.

2. Bortolon LNM, Triz LDPL, Faustino BDS, de Sa LBC, Rochal DRTW, Arbex AK. Gestational diabetes mellitus: New diagnostic criteria. J Endocr Metab Dis. 2016;6(1):13-9. doi: 10.4236/ojemd.201 6.61003

3. American Diabetes Association. Diagnosis and classification of diabetes mellitus. Diabetes Care. 2010;33(1):S62-69. doi: 10. 2337/dc10-S062

4. Lindsay RS. Gestasional diabetes: Causes and consequences. Br J Diabetes Vasc Dis. 2009;9(1):27-31. doi: 10.1177/14746514 08101644

5. Soewondono P, Pramono LA. Prevalence, characteristics, and predictors of prediabetes in Indonesia. Med J Indones. 2011; 20(4):283-94. doi: 10.13181/mji.v20i4.4 65

6. Purnamasari D, Waspadji S, Adam JMF, Rudijanto A, Tahapary D. Indonesian clinical practice guidelines for diabetes in 
preganancy. J ASEAN Federation Endocrine Societies. 2013;28(1):9-13. doi: 10.1560 5jafes.028.01.02

7. Maryunani A. Buku saku diabetes pada kehamilan. Jakarta: Trans Info Media; 2008.

8. MpondoBCT, ErnestA, DeeHE. Gestasional diabetes mellitus: Challenges diagnosis and management. J Diabetes Metab Disord. 2015;14:42. doi: 10.1186/s40200-015016 9-7

9. Thorkelson SJ, Anderson KR. Oral medications for diabetes in pregnancy: Use in a rural population. Diabetes Spectr. 2016;29(2):98-101. doi: 10.2337/diaspec t.29.2.98

10. Kalra B, Gupta Y, Singla R, Kalra S. Use of oral anti-diabetic agents in pregnancy: A pragmatic approach. N Am J Med Sci. 2015;7(1):6-12. doi: 10.4103/1947-2714. 150081

11. Notoatmodjo S. Metodologi penelitian kesehatan. Jakarta: Rineka Cipta; 2002.

12. Hosler AS, Nayak SG, Radigan AM. Stressful events, smoking exposure and other maternal risk factors associated with gestational diabetes mellitus. Paediatr Perinat Epidemiol. 2011;25(6):566-74. doi: 10.1111/j.1365-3016.2011.01221.x.

13. Cunningham FG, Leveno KJ, Bloom SL, Hauth JC, Rouse DJ, Spong CY. Williams obstetric, $23^{\text {rd }}$ Ed. United States: The McGraw-Hill Companies Inc.; 2010.

14. Perkumpulan Endokrinologi Indonesia. Konsensus diagnosis dan penatalaksanaan diabetes melitus di Indonesia. Jakarta: Perkumpulan Endokrinologi Indonesia; 2015.

15. Rowan JA, Hague WM, Gao W, Battin MR, Moore MP. Metformin versus insulin for the treatment of gestational diabetes. N Engl J Med. 2008;358(19):2003-15. doi: 10.1056/NEJMoa0707193

16. Thacker MS, Petkewicz KA. Gestasional diabetes mellitus. US Pharm. 2009;34(9): 43-8.

17. Whalen KL, Taylor JR. Gestational diabetes mellitus. PSAP2017 Book 1; Endocrinology/ Nephrology; 2017.

18. Blumer I, Hadar E, Hadden DR, Jovanovič L, Mestman JH, Murad MH, et al. Diabetes and pregnancy: An Endocrine Society clinical practice guideline. J Clin Endocrinol Metab. 2013;98(11):4227-49. doi: 10.1210/jc.2013-2465.

19. Kaaja R, Rönnemaa T. Gestational diabetes: Pathogenesis and consequences to mother and offspring. Rev Diabet Stud. 2008;5 (4):194-202. doi: 10.1900/RDS.2008.5.1 94.

20. Bloomgarden ZT. Gestational diabetes mellitus and obesity. Diabetes Care. 2010; 33(5):e60-5. 10.2337/dc10-zb05

21. Cheung KW, Wong SF. Gestational diabetes mellitus update and review of literature. Reproductive Sys Sexual Disord. 2011;S2:002. doi: 10.4172/2161-038X.S2002

22. Chu YS, Callaghan WM, Kim SY, Schmid CH, Lau J, England LJ, et al. Maternal obesity and risk of gestational diabetes mellitus. Diabetes Care. 2007;30 (8):2070-6. doi: 10.2337/dc06-2559a

23. Doshani A, Konje CJ. Review: Diabetes in pregnancy: Insulin resistance, obesity and placenta. Br J Diabetes Vasc Dis. 2009;9(5):208-12. doi: 10.1177/1474651 409350273 